Article

\title{
TREATIES, TRUTHS, AND TRANSGRESSIVE PEDAGOGIES: RE-IMAGINING INDIGENOUS PRESENCE IN THE CLASSROOM
}

\author{
MARGARET KOVACH
}

\begin{abstract}
This essay contemplates the context of treaty and the values it offers as a way to imagine anew a just relationship between Indigenous and nonIndigenous peoples within the particular context of education. It begins with a theoretical meandering of sorts, a 'thinking it through piece', and asks, 'What does the treaty relationship, as envisioned by Indigenous peoples, teach us about critical and respectful pedagogy? What are the tensions and contradictions involved in teaching from and through treaty. The essay then explores the implications of a treaty lens within formal schooling through including both Indigenous and non-Indigenous perspectives. Situating treaty within identity, relationship, and a sacred dialogue, the focus is less on treaty or treaties themselves and but rather explores the spirit and possibility of 'treaty', as imagined by Indigenous peoples, in thinking about transgressive pedagogies and practicing transformative dialogue.
\end{abstract}

\section{Keywords}

Treaty, Indigenous, formal schooling, transgressive, pedagogy, dialogue

\section{Biographical note}

Margaret Kovach is of Plains Cree and Saulteaux ancestry and a member of Pasqua First Nations. She is an Associate Professor at the College of Education, University of Saskatchewan. As an active researcher, Margaret's key interests lie in the field of Indigenous research with a specific focus on the importance of upholding Indigenous knowledges in post-secondary sites as pathway for transforming the academy.

\section{Contact Information}

Margaret Kovach, PhD Associate Professor, Educational Foundations/Educational Administration. College of Education, University of Saskatchewan, 28 Campus Drive, Saskatoon, Saskatchewan

\section{Truths, Treaties, and Transgressive Pedagogies (Part I)}

"Why does being from Treaty Four matter to you?" This was a question asked of me as a result of a recent article submitted for peer review of which I was a co-author. 
The article's focus was on the significance of locating one's self in Indigenous methodological research approaches. In line with the article, I introduced myself and identified as being a member of Treaty Four, a post-confederation treaty (which are numbered one through to eleven), signed by Indian nations and the Crown. The land of which Treaty Four encompasses includes the majority of southern Saskatchewan and small portions of southeastern Alberta and western Manitoba. ${ }^{1}$ Chief Pis-qua, in 1874, was the signatory on behalf of Pasqua First Nation of which I am a member. While the numbered treaties emerged post-contact and in this sense may be perceived by some as a colonial tool -- although this is debatable given the use of treaty pre-contact --, the treaty relationship is predominately viewed as sacred by my Saulteaux and Cree kith, kin, and community.

In reflecting on the above mentioned reviewer's question, and knowing the intended journal was international in scope, I eventually assessed that the reviewer was likely asking for more descriptive information about Treaty Four to clarify for the readership. However, my initial, and arguably a bit baffled, reaction to the question was, "What do you mean why does 'being Treaty Four' matter?" "Because it just does, it always has." Raised cross racially in an adoptive home in a small rural white Saskatchewan community, I always knew I was of First Nations heritage. In the area of Saskatchewan were I was raised, First Nations (or the more common term of the time - 'Indian') meant Treaty, and the two terms were used interchangeably. From the start, 'being treaty' has been a paradoxically imbued identity positioning for me. Once I started school I was readily informed that this was not a privileged positioning rather it was an identity term often accompanied by myriad derogations that laid shame upon a culture of people. Being of this culture, I internalized many of these fallacious assumptions at a young age. Yet, I remained conflicted for the word 'treaty' equally evoked in me impressions of respect, history, endurance and belonging. This knowing was counter to the deficit storying of which I had been exposed in my schooling. It took time, relationships, and study to the reveal that this deficit storying levied upon Indigenous peoples was largely socially constructed by a society fully prepared to dismiss my culture. Such revelations clarified a rampant injustice against Indigenous people that, for me, continues to be as personal as it is political.

As a starting place, the personal associations that treaty induces for many suggest that it is intrinsically multifaceted as it is not simply an accord or event, for many of us it is bound in identity. Thus this paper explores 'treaty' as a complex concept. It is about 'identity', however, to consider treaties as solely a categorical demarcation of identity demonstrates a limited understanding of Indigenous culture and philosophy. Treaty marks an on-going relationship with, and including expectations and obligations from,

${ }^{1}$ Saskatchewan is covered by the numbered treaties $2,4,5,6,8$, and 10. 
the Crown and the original newcomers. It is not the piece of paper that was signed at the time but that the parties did smoke the pipe that lends this treaty its force of weight and thus is relationally sacred. Situating treaty within identity, relationship, and a sacred dialogue, this writing focuses less on treaty or treaties themselves as historic documents but rather explores the spirit and possibility of treaty, as imagined by Indigenous peoples, in thinking about transgressive pedagogies.

This essay has two parts. The first section integrates my contemplation on the context of treaty and the values it offers as a way to imagine anew a just relationship between Indigenous and non-Indigenous peoples. This section is a theoretical meandering of sorts, 'a thinking it through piece', and asks, 'What is a treaty?' What does the treaty relationship, as envisioned by Indigenous peoples, teach us about critical and respectful pedagogy? What are the tensions and contradictions involved in teaching from and through treaty. The second part of this essay considers the meaning of treaty broadly and within a formal schooling context. Treaty is considered in the light of conversations with non-Indigenous education faculty members through a small research project inquiring into their perspectives on integrating Indigenous perspectives into their course instruction. The study emphasized Indigenous knowledges however more often than not veered toward Indigenous-settler relations within a social justice pedagogical context. Stated explicitly or not, it is here that a treaty perspective has particular relevancy in the contemporary classroom given its Indigenous traditional role in the maintenance of peaceful relations. More precisely, re-thinking treaty within classrooms in a manner that serves a just peace is critical to a social justice pedagogy given that Indigenous-settler relations have been often been characterized by domination that passes for peace from the perspective of (too) many in the settler population.

\section{“Treaty Is Not A Thing”}

The term 'treaty' within Indigenous-settler context is meant to represent a contemporary relational covenant grounded in a historic agreement. It envisions treaty with regard and with polychromatic potential as opposed to the disparaging, monochromatic manner in which the Canadian government has approached existing treaty relationships. Treaty is conceptualized in the manner in which Indigenous nations may have historically used treaty - as a living, mutually agreed upon protocol used to create and regulate respectful citizenry relationships. In a CBC interview with Jennifer Clibbon (May 22, 2012), Taiaiakie Alfred offers this perspective:

Treaties were made between European settlers and the original people of this land; promises of peace and friendship and co-operation that allowed white people to settle in North America and survive and prosper with the 
help of the original people of this land. The Crown guaranteed those promises would be kept. Canada inherited all of the obligations, and then broke all of the promises once it became its own country. The Royal Proclamation of 1763 and treaties still matter because they are records and evidence of the true relationship that should exist between Canada and indigenous peoples.

The treaties, signed between Indigenous nations and the Crown of territory now known as Canada, signify a nation-to-nation relationship. John Borrows $(2005$, p. 3$)$ states treaty relationships pre-date settlement and were used, as with feasting, trade and intermarriages, as a means of maintaining peaceful relationships. Post-settlement, treaties continued to be a familiar method to clarify relationships most particularly about the land and its bounty. As Borrows (2005) says, "Aboriginal peoples have a preoccupation. It is of land." Post-settlement and amid a long cold season of dispossession he goes on to say: "This dispossession has led to another Aboriginal pre-occupation. It is with the land" (p. 3). Alongside land, Alfred asserts, treaties "still matter" (Clibbon, 2012) to Indigenous peoples as value imbued protocols that identify how people ought to relate with each other on and with the land. Dale Turner (2006) states that, "The treaty position, in its various forms, takes the political stance that the treaties represent not only binding political agreements but also sacred agreements..." (p. 26). He goes on to say that to violate such agreements is a moral encroachment.

Thus, it is worth insisting on this truth: treaty is not a 'thing'. It is a word that describes an active relational process that includes seeking continuous counsel and dialogue on matters that have bearing on the parties it involves. Without societal counsel and dialogue we become a robotic culture void of a richness of being and move increasingly toward a 'thing' like state. "The product of this anti-dialogical culture of domination is the culture of silence, characterized by hopelessness, passivity, self-doubt, where to be is to be under" (Lloyd, 1972, p. 7). There would be no worse irony than for treaty discourse in educational sites to transform the potentially subversive idea of treaty, with its emphasis on ongoing dialogue among peoples, into a dead document of history one item among many in a curriculum that seeks to ready students for a job market and not for life as citizens in a still-colonized land.

\section{"It is not necessary, they argue, that crows be eagles"}

The intersection of a treaty philosophy that is cognizant of a present, imagining the future, but ever mindful of the not quite lost bounty of the past is the contribution, and often currency, of transgressive Indigenous pedagogy. The point is not a nostalgic revalorization of the past for its own sake. Rather the aim is to embody and prefigure a 
vital Indigenous presence that draws its strength in part from the knowledges and struggles of the past, while building the relations now that are necessary for a just and peaceful present and future. Remembering the past is not 'at the expense of but critical to the present and future of peaceful co-relationships.

Acknowledging, without dismissing the past, shows respect for the history from which our current individual and collective narrative has evolved. This does not always happen in contemporary classrooms. For example, the numbered treaties in Saskatchewan have been in place since the 1870s, with Treaty Two signed in 1871. If my math serves me, that would be 142 years ago. It's been awhile. Still when I walk into my classroom, I will be greeted by terminology confusion between treaty, status, and nonstatus, Aboriginal. 142 years and these basics are still widely unknown. And of course, this is not just confusion about terminology (although this cannot be understated). These terms are freighted with different political meanings and entitlements and also with the heavy emotional weight of questions of Indigenous belonging and identity. The lack of understanding within majority culture is indicative of an educational system that has responded to Indigenous experience with: a) active suppression or b) chronic apathy. Were treaty a historical event of the past inconsequential to contemporary relations it would not evoke a response indicative of an active relational status.

This suppression of Indigenous values and experience within sites of dominant discourses as formal educational institutions in Canada has given way to an Indigenous counter narrative within education (Archibald, 1995; Battiste, 2002; Cajete, 1999; Hampton, 1995, Williams and Tanaka, 2007). From this counter-perspective, a philosophy has re-emerged which presupposes human relations that are dialogic and consultative and although affective and holistic such relations are not anti-intellectual. It is a treaty philosophy that shows evidence of a mutual respect and infers a symbiosis of self and other. It reflects, as Vine Deloria (1983) writes, a "true humanism" of an Indigenous cultural belief system. Of tribal peoples, he says,

They revere and recognize the growing process. They establish with some degree of clarity the difference which gender creates in human perspectives. They admit that family considerations play a critical role in the distribution of goods and the application of justice. They recognize law but they also see the fullness of the moment and ask legal and political solutions to be just as well as lawful. They reject a universal concept of brotherhood in favor of respectful treatment of human being with whom they have contact. It is not necessary, they argue, that crows be eagles. ( $p$. 136)

Such a philosophy underscores a treaty relationship (or ought). It offers, for example, an alternative to sweeping educational policy that privileges policies on standardized 
curriculum and testing in formal learning. Overwhelmingly institutions of formal education define success as transforming all crows into eagles! Indigenous perspectives offer an alternate counter perspective, a different way of being and learning in the world. Yet, in asserting culturally grounded philosophical positioning within contemporary contexts, Indigenous peoples experience the added tension of a colonial accounting of both individual and collective identity. This is imbued with multi-layered assumptions, both by dominant culture and those internally colonized, about Indigenous peoples whereby much time is spent explicating who we are in contrast to a frozen-in-time identity. Romanticized notions of how Indigenous people live their lives do not help to further Indigenous (treaty) philosophy as viable and contemporary. Such notions contribute to notions of treaty as an historic artifact and Indigenous culture as dead. Rather, it is in contemporary interpretations based upon ancestral teachings that assure the vitality of the cultures.

\section{Teaching Treaty or Treaty Teachings?}

Given the complexities, teaching from and through an Indigenous and treaty perspective implies the tension of teaching from differing worldviews and temporal states of past, present, and future. Leroy Little Bear (2000) outlines the tensions that inhabit contemporary Indigenous consciousness.

No one has a pure worldview that is 100 percent Indigenous or Eurocentric; rather, everyone has an integrated mind, a fluxing, and ambidextrous consciousness, a precolonized consciousness that flows into a colonized consciousness and back again. It is this clash of worldviews that is at the heart of many current difficulties with effective means of social control in postcolonial North America. It is also this clash that suppresses diversity in choices and denies Aboriginal people harmony in their daily lives (p. 85)

Negotiating the 'ambidextrous consciousness' is experienced as a split, and suggests a capacity, for those destined to move back and forth between the dominant Eurocentric paradigm and an Indigenous consciousness. For many Indigenous educators, there is an emotional and psychic cost to constantly negotiating these dual, often contradictory awarenesses and ways of doing and being. A treaty philosophy does not argue against the contradictions that define the tensions of freedom. Indeed, as Franz Fanon proposes it is the tensions of freedom which create the possibility for "...the ideal conditions of existence for a human world" (1967, p. 231). However, the desire to find ground amid 
tensions and contradictions, the ability to problematize and disrupt normative practices, is often hard won in local educational environments.

My context is Saskatchewan and I am writing with this locale in mind partly because it is my place and partly because the demographic, at this point in time, offers an increasingly possible numerical equality if not social equity between Indigenous and nonIndigenous Saskatchewanians. A study of the Canadian Plains Research Centre projects that the Aboriginal population will be 33\% of the total Saskatchewan population by 2045 (Anderson, 2007). The numbers alone are causing some shifts within public policy and discourse not least of which within education. The latest message heard by sectors of the Saskatchewan population is that we are all treaty people, a statement that is partly a response to the undeniable and growing demographic weight of the Indigenous population in the province. Some know the statement from scholastic writings as the 2008 book We are all treaty people: Prairie essays, authored by Roger Epp. Epp argues that both Indigenous peoples and settlers in Canada inherit the treaty relationship with many difficulties and tensions but also possibilities rooted in respectful dialogue. Some associate it with educational policy arising from the 2008 commitment that the Saskatchewan Office of the Treaty Commission (OTC), Ministry of Education, and the Federation of Saskatchewan Indian Nations (FSIN) would be moving forward with mandatory treaty education in the province (Government of Saskatchewan). And some are peripherally aware of this statement as part of a broader cultural sentiment that is for the most part unthreatening in its abstraction.

We are all treaty people suggests that treaty involves all Saskatchewanians and since 2008 the public school system requires mandatory treaty education throughout K12. Essential treaty teachings, ${ }^{2}$ as developed by the OTC, Ministry of Education and FSIN, are part of the required provincial curriculum "for all students, in all grades, and in all subject areas" (Tupper, 2011, "Disrupting Ignorance," para. 2). Treaty education within formal western schooling cannot help but trouble the critically conscious mind. Henry Giroux (2011) offers a critique of formal schooling that is factory-like in its desire to meet its goals. In this example, Giroux comments upon the allegiance of formal education to the job market but this critique can be equally applied to 'treaty education' delievery. Giroux states: "Few of even the so-called educators ask the question: What matters beyond the reading, writing, and numeracy that are presumably taught in the elementary and secondary grades? These unasked questions are symptoms of a new regime of educational expectations that privileges job readiness above any other educational value" (p. 4). In this context, there is a very real risk of dialogic opportunities being skirted thus leaving 'treaty education' in the classroom void of meaning. As Jennifer Tupper and Michael Capello (2008) state, “...when students do not understand the ongoing

${ }^{2}$ For more information about Treaty Kits please see Saskatchewan Office of the Treaty Commissioner at http://www.otc.ca/Treaty_Kit_K12/ 
significance of treaty relationships, it matters little the number of times the word treaty appears in curriculum documents" (p. 576). While "teaching treaty" accompanied by an ambiguous, we are all treaty people, slogan discourse warrants skepticism I am optimistic that if held to Indigenous principles accompanying historic treaties, there is potential for critical citizenry schooling here. However, much depends upon an educator's ability to facilitate and contribute toward this dialogue in a manner that takes treaty relations seriously, that moves beyond teaching treaty as an historical artifact to that of a living protocol for how to exist in a world that is honourable, just, and caring of each other.

There are options in teaching treaty. Educators can stay safe by limiting themselves to re-inscribing a colonial cultural standard account. Or we, as educators, can make a choice. In considering critical pedagogy Peter McLaren (2008) reminds us that, "Freire has helped us to fathom the complex and variegated dimensions of our everyday life as educators. He has helped us, in other words, not to believe everything we think!" (p. 476). In teaching treaty there is a possibility that "...would enable the creation of an (un) usual narrative" (Tupper and Cappello, 2008, p. 570). Shake things up, expose racism inherent in the standard accounting, offer to tell another side of the story. What if instead teaching treaty was more about teaching through a particular relational lens. What would that look like? I start to think about myself as part of a community of educators. What if, as McLaren (2008) reminds, in "the complex and variegated dimensions of our everyday life" we taught as if treaty mattered?

The next, and second section, of this paper is reflective of an "ambidextrous" shift whereby non-Indigenous voices are introduced. The first section of this paper highlights treaty, as envisioned by Indigenous peoples, as a relational protocol between Indigenous and settler peoples for purposes of peaceful co-habitation. A treaty pedagogy, at its most powerful, integrates dialogic respectful truth telling to meet this end. The first part of this paper has largely been truth telling by Indigenous peoples on treaty (focused within an education context). The second part of this essay includes the voices of non-Indigenous post-secondary educators and their experience with Indigenous perspectives in their classroom. The voices are from a qualitative study I recently completed where individuals were asked about the experience of including Indigenous knowledges into their teaching. They were not specifically asked about teaching treaty but the conversations inevitably spoke to the core Indigenous philosophy inherent in a treaty perspective and the significance of anti-colonial work. Interestingly, as treaty teaches us, the conversations were largely relationally situated within the dialogue illuminating the push/pull dynamics of human relationships where hesitancies and uncertainties were present.

\section{Truths, Treaties, and Transgressive Pedagogies (Part II)}

“...I think it's maybe less that I include Aboriginal or Indigenous content as that I 
try to make space for it" (B3). “...in my head I conceptualize that [Indigenous Knowledge] as some body of knowledge that there is to know and I don't know that... but the social justice piece... that's all comfortable for me" (C3).

Certainly unpacking power and privilege as it applies (or does not) to Indigenous peoples and knowledges is a denotative function of transgressive pedagogies. "Teachers need to be aware of and able to interrupt the repetitive neoliberal discourses that cut off students and their families through notions of individualism, power, and mistrust." (Sandford, Williams, Hopper, McCregor, 2012, Indigenous principles, para 2). Transgressive pedagogies secure space for non-western approaches, including but not only Indigenous perspectives, that contest a corporatism, and the values thereof, increasingly found within institutions of higher learning. The possibilities, for example, to crack open "repetitive neoliberal discourse" (Sandford et al, 2012) in authentic treaty dialogue are numerous.

Yet in casting a critically reflective gaze on the increased interest of Indigenous knowledges within education (and given mandatory treaty education in Saskatchewan) one cannot but help but speculate on the extent to which an Indigenous belief system itself is comprehended within post-secondary sites. In my conversations, educators were consciously striving to resist a white solipsism rendering European culture as normative and were cognizant of the limits of an "add and stir" approach to Indigenous perspective and experience. And although there was an understanding of complexities of the inquiry topic, one did not have to 'drill' too far down into the data to find a residual sub-text swirling around Indigenous knowledge systems in the classroom and lingering questions. Can one show deference to a knowledge system imbued with manifestations of its culture, but evade attention to those same manifestations for fear of not being respectful or perceived as such? If one is to acknowledge Indigenous peoples what theoretical perspective will assist in summoning respectful engagement - critical, structural, postmodern, postcolonial, Indigenous relational? What is respectful? What is helpful? Do we know?

As a transgressive stance against white appropriation and in support of identity standpoint voice some would argue that non-Indigenous instructors leave the Indigenous pedagogy to Indigenous people. However, with only 2\% (Eisenkraft, 2010) of current post-secondary faculty members in Canada being of Indigenous heritage this poses some pragmatic difficulties. From a teacher preparation perspective - leaving it to the Indigenous faculty - is somewhat problematic when we are expecting less learned teacher candidates to teach to Indigenous perspectives in their K-12 classrooms. It begs the question as to whether we are asking teacher candidates to do as I say not as I do? Further as Canadian citizens (certainly academics) should we not be prepared to lead informed discussions on aspects of Indigenous experience, treaties being a particularly good example, from both a western and Indigenous perspectives? Where do we, as educators, begin to interrogate our choices that shape our responses? Likely it is close to 
home.

\section{Truths, Tensions, Hesitancies}

We're doing a not terrible job about providing our undergraduates with some knowledge of the history, their role in it and on one level that's understood. You're doing a lot of that work, but then you've got the critical ability to take a look at that and really question your own identity and role within it, that's hard work (D1).

As the above quote suggests, the relation of non-Indigenous educators to Indigenous pedagogy is complicated, even among those basically sympathetic and seeking to act in solidarity with Indigenous colleagues. This engagement may require painful and even intellectually difficult to grasp introspection and reflexivity, as the first speaker suggests. It may mean distancing yourself from your own history as a settler and it may raise questions about 'compensation' across generations that have no straightforward answers as articulated in this reflection, “... I can never compensate for the actions of my ancestors. I don't even want them to be my ancestors, always wanting to compensate, but how can you do that?" (C3). Non-Indigenous educators may so fear being offensive that avoidance of Indigenous questions becomes the 'moral' way of avoiding addressing the Indigenous-settler relationship, “...you get paralyzed because you're afraid you'll do the wrong thing and so then you don't do anything or you skirt it..." (C2).

The intrapersonal aspects of transgressive pedagogies are ever evident, powerfully sensed and felt, if not always spoken. There are some theoretical supports for the difficult task of reflexivity, among settler educators. Notably, a theoretical focus on anti-oppressive education as in Kumashiro's work (2000) has given rise to an entire sub-section on whiteness studies to explore this phenomenon for white educators. (Aveling, 2004; Adair, 2008; Nicoll, 2004; Preston, 2007; Schick, 2002). Jennifer Adair (2008) states critical race scholars "...have been pushing teacher educators to look closely at the reproduction of White privilege..." (p. 190). In deconstructing the maintenance of racial privilege within sites of education, transgressive pedagogies like anti-racism offer a portal for critical reflection on Whiteness (Preston, 2007; Schick, 2002). Anti-racist pedagogy, concerning itself with structural inequities, have interrogated the marginalization of racial minorities (O’Brien, 2009; Dei, 1996). Within the literature that has decolonizing foci, the colonial relational dynamic of identities that allow the denigration of Indigenous peoples is a pivotal point of analysis (Battiste, 1998; St. Denis, 2007). Educators, in literature and in primary voice, speak of interrogating their own sense of complicity and guilt of being players in the oppression of Indigenous peoples. To move through the critically reflective affective dimension is part of the process and because it has been heard before it does not 
mean it is finished work. As Elder knowledge tells us when it comes to the heart we talk until the talking is done. Transgressive pedagogies, which at their core are relational pedagogies, move nowhere without this work.

On a more practice level, individuals equally reflected upon integrating an Indigenous philosophy into their teaching often articulating it as a holistic approach. While there was seemingly less resistance to the challenges for a holistic orientation it, too, pushes against the strong current of an outcome-orientated approach - the primacy of methods curricular approach - found within western educational institutions. While there is support here there is also caution. Scholars as George Sefi Dei (2002) argue for a hybridity of knowledges in learning sites but cautions that the integration of Indigenous knowledges into "...curricular, instructional and pedagogical practices of Western academies cannot be an unquestioned exercise" (p. 17). He goes on to say that hierarchical social relations must be considered as to how they are "...used to validate different knowledges to serve particular interests" (p. 17). Theoretically most postsecondary educators (or at least the allies) understand the contradictions and tensions or at least say they do. Possibly many appreciate the potential of a rich exploration of, and immersion in, Indigenous education does not currently exist in formal education without potential vulnerability to pedagogical distortions antithetical to treaty. "Teach about the treaties right? You can have a kit and the problem with that entire thing is you do the kit and then you forget it for the rest of the year" (D1).

Given the reflexive, critical perspectives referenced, change remains slow and the experience in contemporary classrooms, by educators, continues to reflect Little Bear's insights on an 'ambidextrous consciousness' as stated here: "I've tried that kind of thing [holistic pedagogy] with non-Aboriginal students and it doesn't work very well. It's just the whole way of being is so different that here is a space where emotions need to be kept in check..." (A1). In other words, the 'ambidextrous consciousness' is not easily deployed, perhaps especially by non-Indigenous educators who are already uncomfortable about their limited exposure to Indigenous ways of educating. These educators confront resistance to Indigenous ways of thinking by non-Indigenous students, who may have an 'emotional' reaction: this might be a coded way of acknowledging the difficulties non-Indigenous students have in recognizing their own complicity in colonial ways of thinking. To avoid 'painful' recognition of the colonial relationship, and maybe even the limits of dominant Western ways of knowing, it may be easier just to ignore holistic Indigenous approaches that - given this resistance by nonIndigenous students - 'don't work very well'. I consider my own complexities as an Indigenous educator, my own contradictions. Within current landscape of inequities that limits authentic reconciliation, the risk of cultural appropriation, the politics of representation, discourses on complicity, and post-binary hesitancies, respectful inclusion is complex and no small task.

Amid the challenges voices from this research also expressed the possibilities 
inherent in a relational approach. “...It's about respect ... and bringing someone else along from behind. I think that also fits with Indigenous perspectives about caring and being ready" $(\mathrm{C} 1)$.

Here, the issue is about relationships, acceptance, respect, about caring and being ready - and open to dialogue, “...I really think it is about building relationships and accepting people for being, for thinking and being, different then you are" (A3). Thus we return to personal choices and what it means in a relational sense linked with the idea of ongoing respectful, caring, accepting dialogue. It is about being, at least, prepared to meet and talk with the 'other' if complicated by the fact that relations are not equal, but riven with power, and that trust and respect in such unequal power relations is very difficult to establish.

\section{“To engage in dialogue..."}

David Jefferess (as cited in Regan, 2010) suggests efforts that transformative relationships are those that dissolve the persisting binaries that maintain a colonizercolonized identity and "...constitutes an interrelated process of material and cultural transformation and not just interpersonal reconciliation..." (p. 214). It is the material and cultural transformation aspect of this analysis that is the antidote against a postbinary neoliberalism. Alfred (2010) advises that true respectful co-existence can only exist when those that benefit from colonial empiricism emotionally disengage from their countries and re-imagine themselves "...as human beings in equal and respectful relation to other human beings and the natural environment" (p. 6).

The literature and my own experiential knowledge suggest that inquiring into Indigenous education through a treaty lens means recognizing a relational dynamic involving power, people, structures, and the ability to trust (or proceed in its absence). Willie Ermine (2007) proposes that, "...ethical space, at the field of convergence for disparate systems, can become a refuge of possibility..." (p. 203). As Dei (2002) tells it welcoming a hybridity of knowledges in the academy matters given that our "...interconnected world is ever more critical in this information era" (p. 4). However, there is no magical formula or theoretical wizardry that will move us there within institutional five-year plans. Dei (2002) further asserts Indigenous knowledge is resistance knowledge within the academy and that resistance is about "...using received knowledges to ask critical questions about the nature of the social order. Resistance also means seeing 'small acts' as cumulative and significant for social change" (p. 17). It demands dialogic associations, and if treaty teaches us anything, it teaches us about relationships, particularly about relationships of power.

Whether in the autobiographical, theoretical, or qualitative realm walking this road has not been an unencumbered relational journey with politics of representation 
intersecting with the psychology and sociology of insider/outside status. This is set within the differing perspectives of whether to centre the settler through anti-colonial discourse, uphold Indigeneity through honoring culture, or to do both within the prickly place of co-existence. Increasingly fewer openly dispute Battiste's (as cited Brayboy \& Maughan, 2009) analysis that, "Indigenous Knowledge is systemic and systematic and has an eternal consistency" (p. 4). However, this remains set within a critical discourse on “...contradictions and paradoxes of cultural revitalization..." (St. Denis, 2007, p. 1075) as the totemic curricular treatment of Indigenous content and the overall problematic of meshing relational based knowledge systems into outcome-based curricular models void of an anti-racist perspective. A useful strategy will include, then expand upon, the transformative capacities of anti-colonial analysis toward a co-existence that pragmatically and theoretically challenges binaries that, as Jefferess (as cited in Regan, 2010) indicates, entrench the colonizer-colonized identity. bell hooks tells us such possibilities begin with dialogue, "To engage in dialogue is one of the simplest ways we can begin as teachers, scholars and critical thinkers to cross boundaries, the barriers that may or may not be erected by race, gender, class, professional standing, and a host of other differences." (hooks, 1994, p.130). Treaty at its core is dialogic and talking with is powerful. As a society and as educators, we ought to at least respect that.

\section{Concluding Reflections}

The intersection of treaty and teachings cannot be concluded without mention of Idle no more and the conscientization of community. Four women ${ }^{3}$ from Saskatchewan initiated this movement in response to Bill C-45. Bill C-45, a 400 page plus omnibus budget bill, includes a number of sections having direct impact on First Nations ${ }^{4}$. Along with the sections pertaining specifically to First Nations, Bill C-45 allows for substantial changes to the Navigational Waters Protection Act that limits environmental stewardship regulation. This last change alone would limit inherent Indigenous stewardship over the land. The promise to be 'Idle no more' given flagrant disregard for treaties as a relationship by the Canadian Conservative government, sparked and spread through social media, generated a participatory citizenry response to Bill C-45. Idle no more is an

\footnotetext{
${ }^{3}$ Idle no more was initiated by four Saskatchewan women, Jessica Gordon, Sheelah McLean, Sylvia McAdams and Nina Wilsonfeld.

${ }^{4}$ Section of C-45 includes: Bill C-27 First Nations Financial Transparency Act; Bill S-2 Family Homes on Reserve and Matrimonial Interests or Right Act; Bill S-6 First Nations Elections Act; Bill S-8 Safe Drinking Water for First Nations; Bill C-428 Indian Act Amendment and Replacement Act; Bill S-207 An Act to amend the Interpretation Act; Bill S-212 First Nations Self-Government Recognition Bill and the "First Nations" Private Ownership Act. These different Bills collective attack and seek to unilaterally alter Indigenous rights in a wide range of domains, from financing to band elections to property rights.
} 
expression of growing frustration by Canadians who feel increasingly feeling unheard and marginalized; Indigenous resistance is a, maybe the, critical element of this response, an insistence on the fact of the Indigenous-settler relationship, a relationship that can only go forward through meaningful dialogue among all peoples. Through round dances, flash mobs, and teach-ins, Idle no more is about creating awareness of the role of treaty in stewardship of the earth and how this matters to all not just Indigenous peoples.

The Idle no more movement is not about any one issue but about many related concerns. Idle no more reflects a specific perspective on environmental activism which some have referenced as "Indigenous environmentalism" (Wherry, 2012, December 18, para 1), which is concerned with the protection of sacred sites and the land, water and air. To many this response to Bill C-45 is about treaty, the insistence on respectful dialogue among Indigenous and settler peoples and the infringement by the Canadian state on treaty relations inherent in Bill C-45, in particular the lack of adequate consultation on matters impacting treaty lands. Yet, the movement has resonance beyond the Canadian context. Idle no more has been a portal for global voice with expressions of solidarity from Palestinians in Nazareth, Maori in New Zealand and Indigenous peoples in the United States, among others (Hahn, 2013, January 4). January 11, 2013 was a global day of action, solidarity and resurgence. The wide-ranging and global scope of the Idle no more movement, which has sometimes been criticized for its supposed lack of focus, is indicative of the range of issues that are bound up with grappling with relations among Indigenous peoples and settlers.

The Indigenous role in the Idle no more movement is as complex and contradictory as the many Indigenous peoples in what is now Canada. Nonetheless, part of the movement can be understood from the perspective of the meaning of treaties for Indigenous peoples. "For the First Nations of this province, the Treaties did not signify cession or surrender to Canadian authority but rather the establishment of a nation-tonation relationship" (Pitawanakwat, 2007). Because treaty signifies a nation-to-nation relationship and not land cessation there is an obligation felt on behalf of many First Nations to continue to protect the land and its resources. Through its focus on treaty rights Idle no more gives voice to a stewardship that predates the likes of greenhouse gas emissions, contamination of water bodies, and the generally consistent horrific (and stupefying) violations of mother earth. Indigenous environmentalism is a contemporary term for longstanding Indigenous stewardship of the land of which treaty represents. For First Nations people, the response to Bill C-45 and the Idle no more movement is an example of what Borrows (2005) describes as a pre-occupation of and with the land. Idle no more is one example of necessary dialogue in, or outside, the formal classroom.

This is the kind of dialogue that makes up critically reflective educational environments, environments in which we can all consider who we are (and what we believe) as a local, regional, national, and global citizenry. The classroom (either inside or 
outside of formal schooling) is a potential site where this kind of education can take place, a kind of education that will, as Giroux states (2011), tackle the question of "what a kid needs to become an informed 'citizen' capable of participating in the large public decision that affect the larger world..." (p. 4). A treaty education, for Canadians, holds the potentiality for conversations that investigate a multiplicity of worldviews, contrasting political process, environmental stewardship, and differing economies. A genuine treaty education would bring the debates opened up dramatically by the Idle No More movement into the classroom, as well as taking place outside of it.

Concluding this paper, I return to the pragmatics of the classroom. Transgressive pedagogies in anti-colonial, post-binary learning environments can not start and end on whether there ought to be a medicine wheel on a classroom wall or as Tupper and Cappello (2008) state, "...the number of times the word treaty appears in curriculum documents." (p. 576). We have to move beyond a dialectic on the totemic to consider what each of the above could possibly summon. Could it not be a relational invitation to gain a deeper sensibility of the people, values, context, experience, and particularities associated with the representation? This invitation to critical reflection ought to be extended within a pedagogy attuned to the colonialist enterprise that Indigenous peoples have endured as well as serve as a pathway toward creating a mutually beneficial coexistence. What if the teaching treaty was less symbolic of the past and more a representational insignia of a new approach to schooling. What if?

In my undergraduate teaching, I include an opportunity for student's to work with Indigenous knowledges and methods. This is scheduled after consideration of anticolonial perspectives. I cannot deny there have been times when I have seriously questioned whether allowing space for largely young white students to take up Indigenous approaches is doing anyone any favors. Still, I have largely been overwhelmed by the respectfulness and desire by my students to do better then what they have been taught, to see themselves as teachers with an Indigenous sensibility. The challenge is not, has never been, solely about teaching treaty rather it has always been

about teaching through treaty with all the respect and understanding with which the treaties have the potential to afford us all.

\section{References}

Adair, J.K. (2008). White pre-service teachers and "De-privileged" spaces. Teacher Education Quarterly, 35(4), 189-206.

Alfred, T. (2010). What is radical imagination? Indigenous struggles in Canada. Affinities: A Journal of Radical Theory, Culture, and Action, 4(2), 5-8. 
Anderson, A. (2007). Aboriginal Population Trends. In The encyclopedia of Saskatchewan (2006 ed.). Retrieved from http://esask.uregina.ca/entry/aboriginal_population_trends.html

Archibald, J. (1995). Locally developed native studies curriculum: A historical and philosophical rationale. In M. Battiste (Ed.), First Nations education in Canada: The circle unfolds. (pp. 288 - 312). Vancouver: UBC Press.

Aveling, N. (2004) Critical Whiteness studies and the challenges of learning to be a White ally, Borderlands, 3 (2). Available online at: www.borderlandsejournal.adelaide.edu.au/issues/vol3no2.html (accessed April 2005).

Battiste, M. (1998). Enabling the autumn Seed: Toward a decolonized approach toward Aboriginal knowledge, language and education. Canadian Journal of Native Education, 22(1), 16-27.

Battiste, M. (2002). Indigenous knowledges and pedagogy in First Nations education: A literature review with recommendations. Ottawa: National Working Group on Education.

Borrows, J. (2005). Crown and Aboriginal occupations of land: a history \& comparison. Research Paper prepared for the Ipperwash Inquiry, Toronto: Government of Ontario.

Brayboy, B. \& Maughan, E. (2009). Indigenous knowledges and the story of the bean. Harvard Educational Review. 79 (1), 1-21.

Cajete, G. (1999). Native Science: Natural laws of interdependence. Santa Fe, NM: Clear Light Publishers.

Clibbon, J. (2012, May 22). The “special relationship' of native peoples and the crown: Relationship cemented in $18^{\text {th }}$ century matters still. CBC News. Retrieved from http://www.cbc.ca/news/canada/story/2012/05/22/f-crown-native-peoples.html

Dei, G. (1996). Anti-Racism Education: Theory and Practice. Halifax: Fernwood Publishing. 
Dei, G. (2002, March). Rethinking the role of Indigenous knowledge in the academy. Lecture paper presented at the Studies in National and International Development, Queen's University, Kingston, Ontario.

Deloria, V. (1983). Circling the same old rock. In W. Churchill (Ed.), Marxism and Native Americans. (pp. 113-137). Boston: South End Press

Ermine, W. (2007). The ethical space of engagement. Indigenous Law Journal, 6 (1), 193203.

Eisenkraft, H. (2010). Racism in the academy. University Affairs. Retrieved from http://www.universityaffairs.ca/racism-in-the-academy.aspx

Epp, R (2008). We are all treaty people: Prairie essays. Edmonton: The University of Alberta Press

Fanon, F. (1967). Black Skin White Masks. New York: Grove Press.

Giroux, H. (2011). Rejecting academic labor as subaltern class: Learning from Paulo Freire and the politics of critical pedagogy. Fast Capitalism, 8.2. Retrieved from http://www.uta.edu/huma/agger/fastcapitalism/8_2/Giroux8_2.html

Hahn, P. (2013, January 4). Idle no more movement goes global. Retrieved from http://www.ctvnews.ca/canada/idle-no-more-movement-goes-global-1.1101386).

Hampton, E. (1995). Towards a redefinition of Indian education. In M. Battiste (Ed.), First Nations education in Canada: The circle unfolds. (pp. 5-46). Vancouver: UBC Press

hooks, B. (1994). Teaching to Transgress: Education as the Practice of Freedom, London: Routledge

Kumashiro, K. (2000). Toward a theory of anti-oppressive education. Review of Educational Research, 70 (1), pp. 25-53.

Little Bear, L. (2000). Jagged worldviews colliding. In M. Battiste (Ed.), Reclaiming indigenous voice and vision. (pp. 77-86). Vancouver, BC: University of British Columbia Press. 
Lloyd, A. (1972). Friere, conscientization, and adult education. Adult Education, XXIII (1), p. 3-20.

McLaren, P. (2008). This fist called my heart: Public pedagogy in the belly of the beast. Antipode, 40 (3), 472-481.

Nicoll, F. (2004). “Are you calling me a racist?": Teaching critical whiteness theory in Indigenous sovereignty. Borderlands 3 (2). Retrieved from http://www.borderlands.net.au/vol3no2_2004/nicoll_teaching.htm.

O'Brien, J. (2009). Institutional racism and anti-racism in teacher education: Perspectives of teacher educators. Irish Educational Studies, 28 (2), 193-207.

Pitawanakwat, B. (2007). Aboriginal Treaty Rights. In The encyclopedia of Saskatchewan (2006 ed.). Retrieved from http://esask.uregina.ca/entry/aboriginal_treaty_rights.html

Preston, J. (2007), Whiteness and Class in Education. Dordrecht: Springer.

Regan, P. (2010). Unsettling the settler within: Indian residential schools, truth telling, and reconciliation in Canada. Vancouver, B.C: UBC Press.

Sandford, J., Williams, L., Hopper, T. \& McGregor, C. (2012). Indigenous principles informing teacher education: What we have learned. In Education, 18 (2). Retrieved from http://www.ineducation.ca/article/indigenous-principlesinforming-teacher-education-what-we-have-learned

Schick, C. (2002). Keeping the ivory tower white: Discourses of racial domination. In S. Razack (Ed.), Race, space, and the law: Unmapping a White settler society. (pp. 99119). Toronto: Between the Lines Press.

St. Denis, V. (2007). Aboriginal education and anti-racist education: Building alliances across cultural and racial identity. Canadian Journal of Education, 30 (4), 10681092.

Tupper, J. (2011). Disrupting ignorance and settler identities: The challenge of preparing beginning teachers for treaty education. In Education, 17 (3). Retrieved from http://ineducation.ca/issue-6 
Tupper, J. \& Cappello, M. (2008). Teaching treaties as (Un)Usual narratives: Disrupting the curricular commonsense. Curriculum Inquiry, 38 (5), 560-578.

Turner, D. (2006). This is not a peace pipe: Towards a critical Indigenous philosophy. Toronto: University of Toronto Press.

Wherry, A. (2012, December 18). \#Idlenomore and the fight for democracy. Beyound the Commons. Retrieved from http://www2.macleans.ca/2012/12/18/idlenomore-andthe-fight-for-democracy/\#

Williams, L. \& Tanaka, M. (2007). Schalay'nung Sxwey'ga emerging cross-cultural pedadogy in the the academy. Educational Insights, 11 (3). Retrieved from http://www.ccfi.educ.ubc.ca/publication/insights/v11n03/articles/williams/william s.html 